\title{
Recrystallization of triple superphosphate produced from oys- ter shell waste for agronomic performance and environmental issue
}

\author{
Somkiat Seesanong 1, Chaowared Seangarun ${ }^{2}$, Banjong Boonchom ${ }^{2,3, *}$, Chuchai Sronsri ${ }^{2}$, Nongnuch Laohavisuti ${ }^{4}$, \\ Kittichai Chaiseeda ${ }^{5, * *}$ and Wimonmat Boonmee ${ }^{6}$
}

1 Department of Plant Production Technology, School of Agricultural Technology, King Mongkut's Institute of Technology Ladkrabang, Bangkok 10520, Thailand

2 Advanced Functional Phosphate Material Research Unit, Department of Chemistry, School of Science, King Mongkut's Institute of Technology Ladkrabang, Bangkok 10520, Thailand

3 Municipal Waste and Wastewater Management Learning Center, School of Science, King Mongkut's Institute of Technology Ladkrabang, Bangkok 10520, Thailand

4 Department of Animal Production Technology and Fishery, School of Agricultural Technology, King Mongkut's Institute of Technology Ladkrabang, Bangkok 10520, Thailand

5 Organic Synthesis, Electrochemistry and Natural Product Research Unit (OSEN), Department of Chemistry, Faculty of Science, King Mongkut's University of Technology Thonburi, Bangkok 10140, Thailand

6 Department of Biology, School of Science, King Mongkut's Institute of Technology Ladkrabang, Bangkok 10520, Thailand

* Correspondence:

* kbbanjon@gmail.com; Tel +66-2329-8400

**kittichai@gmail.com

\begin{abstract}
Calcium dihydrogen phosphate monohydrate $\left[\mathrm{Ca}\left(\mathrm{H}_{2} \mathrm{PO}_{4}\right) \cdot \mathrm{H}_{2} \mathrm{O}\right]$ (a fertilizer) was successfully synthesized by the recrystallization process by using a prepared triple superphosphate (TSP) that derived from oyster shell waste as starting material. This bio-green, eco-friendly process to produce an important fertilizer can promote a sustainable society. The shell-waste-derived TSP was dissolved in distilled water and kept at 30,50 , and $80{ }^{\circ} \mathrm{C}$. Non-soluble powder and TSP solution were obtained. The TSP solution fraction were then dried and the recrystallized products (RCP30, RCP50, and RCP80) were obtained and confirmed as $\mathrm{Ca}\left(\mathrm{H}_{2} \mathrm{PO}_{4}\right)_{2} \cdot \mathrm{H}_{2} \mathrm{O}$. Whereas the non-soluble products (NSP30, NSP50, and NSP80) were observed as calcium hydrogen phosphate dihydrate ( $\mathrm{CaHPO} \cdot 2 \mathrm{H}_{2} \mathrm{O}$ ). The recrystallized yields of RCP30, RCP50, and RCP80 were found to be $51.0 \%$, $49.6 \%$, and $46.3 \%$, whereas the soluble percentages were $98.72 \%, 99.16 \%$, and $96.63 \%$, respectively. RCP30 shows different morphological plate sizes, while RCP50 and RCP80 present the coagulate crystal plates. X-ray diffractograms confirm the formation of both the NSP and RCP. The infrared adsorption spectra confirmed the vibrational characteristics of $\mathrm{HPO}_{4}{ }^{2-}, \mathrm{H}_{2} \mathrm{PO}_{4}-$ and $\mathrm{H}_{2} \mathrm{O}$ existed in $\mathrm{CaHPO}_{4} \cdot 2 \mathrm{H}_{2} \mathrm{O}$ and $\mathrm{Ca}\left(\mathrm{H}_{2} \mathrm{PO}_{4}\right)_{2} \cdot \mathrm{H}_{2} \mathrm{O}$. Three thermal dehydration steps of $\mathrm{Ca}\left(\mathrm{H}_{2} \mathrm{PO}_{4}\right) \cdot \mathrm{H}_{2} \mathrm{O}$ (physisorbed water, polycondensation, and re-polycondensation) were observed. $\mathrm{Ca}\left(\mathrm{H}_{2} \mathrm{PO}_{4}\right)_{2}$ and $\mathrm{CaH}_{2} \mathrm{P}_{2} \mathrm{O}_{7}$ are the thermodecomposed products from the first and second steps, whereas the final product is $\mathrm{CaP}_{2} \mathrm{O}_{6}$.
\end{abstract}

Keywords: $\mathrm{Ca}\left(\mathrm{H}_{2} \mathrm{PO}_{4}\right)_{2} \cdot \mathrm{H}_{2} \mathrm{O}$; Triple superphosphate; Fertilizer; Recrystallization; Oyster shell; Thermal decomposition

\section{Introduction}

Calcium-phosphate based materials, i.e., tetracalcium phosphate $\left(\mathrm{Ca}_{4}\left(\mathrm{PO}_{4}\right)_{2} \mathrm{O}\right)$, tricalcium phosphate $\left(\mathrm{Ca}_{3} \mathrm{PO}_{4}\right)$, calcium dihydrogen phosphate monohydrate $\left(\mathrm{Ca}\left(\mathrm{H}_{2} \mathrm{PO}_{4}\right)_{2} \cdot \mathrm{H}_{2} \mathrm{O}\right)$ or monocalcium phosphate monohydrate (MCPM), calcium hydrogen phosphate $\left(\mathrm{CaHPO}_{4}\right.$ or monetite), calcium hydrogen phosphate dihydrate (Ca$\mathrm{HPO}_{4} \cdot 2 \mathrm{H}_{2} \mathrm{O}$ ) or brushite), octacalcium dihydrogen phosphate pentahydrate 
$\left(\mathrm{Ca}_{8} \mathrm{H}_{2}\left(\mathrm{PO}_{4}\right)_{6} \cdot 5 \mathrm{H}_{2} \mathrm{O}\right)$, and decacalcium hydroxide phosphate $\left(\mathrm{Ca}_{10}\left(\mathrm{PO}_{4}\right)_{6}(\mathrm{OH})_{2}\right.$ or hydroxyapatite) have wildly been investigated $[1,2]$, because there are stable, biocompatible, and similar to the natural teeth and bone. Therefore, they have been used as bone substitutes in biomedical fields [2].

In the agricultural industry, calcium phosphate, essential fertilizer, is called triple superphosphate (TSP) [3]. TSP fertilizer in the form of $\mathrm{Ca}\left(\mathrm{H}_{2} \mathrm{PO}_{4}\right)_{2} \cdot \mathrm{H}_{2} \mathrm{O}$ (or MCPM) provides a high concentration of phosphorous (P) (more than $40 \%$ of diphosphorous pentoxide, $\mathrm{P}_{2} \mathrm{O}_{5}$ ) that became widely used in the 20th century and the most common phosphorous source used in many countries until the mid-1970s for plant development [4]. Phosphorus is one of the macronutrients employed for plant growth that plays an important role in many physiological and biochemical plant activities [5]. One of the advantages of feeding plants with phosphorus is to create deeper and more abundant roots, early maturation, decreasing grain mold, increasing chlorophyll content in leaf, and positively affecting photosynthesis, resulting to the improving of crop quantity and quality [6]. However, the agronomic performance of the fertilizer for plants is limited by its insolubility in water, which has reasoned phosphorus delivery at a very slow rate. To increase the soluble phosphorus contents and purity of the TSP fertilizer, it can be recrystallized to obtain the soluble $\mathrm{Ca}\left(\mathrm{H}_{2} \mathrm{PO}_{4}\right)_{2} \cdot \mathrm{H}_{2} \mathrm{O}$. The TSP was firstly dissolved in water and the filtration technique was then employed to remove the insoluble fraction from the solution. When the dissolved cation and anion species were recrystallized, pure $\mathrm{Ca}\left(\mathrm{H}_{2} \mathrm{PO}_{4}\right)_{2} \cdot \mathrm{H}_{2} \mathrm{O}$ with the solubility property can be recovered [7]. Owing to its high solubility, $\mathrm{Ca}\left(\mathrm{H}_{2} \mathrm{PO}_{4}\right)_{2} \cdot \mathrm{H}_{2} \mathrm{O}$ can be delivers phosphorus at higher rate [7]. Readily soluble phosphorous have the potential to supply phosphorous to plants immediately after application. When the fertilizers (i.e., $\left.\mathrm{Ca}\left(\mathrm{H}_{2} \mathrm{PO}_{4}\right)_{2} \cdot \mathrm{H}_{2} \mathrm{O}\right)$ are used, the moisture existed in soil is absorbed by $\mathrm{Ca}\left(\mathrm{H}_{2} \mathrm{PO}_{4}\right)_{2} \cdot \mathrm{H}_{2} \mathrm{O}$ (in both granular and powder forms). $\mathrm{Ca}\left(\mathrm{H}_{2} \mathrm{PO}_{4}\right)_{2} \cdot \mathrm{H}_{2} \mathrm{O}$ is dissolved leading to the release of phosphorous fertilizer into the soil, followed by the uptake of plants for growth and development.

There are many synthesis methods in the production of calcium phosphates such as hydrothermal [4,6], microwave assisted [8], precipitation [9, 10], sol-gel [11], and electrochemical [12] techniques. The method used in each case depends on the desired type of morphology, structure, and chemical composition. In general, calcium phosphates have been synthesized from phosphoric acid $\left(\mathrm{H}_{3} \mathrm{PO}_{4}\right)$ and commercial calcium $\left(\mathrm{Ca}^{2+}\right)$ sources [7]. However, using shells (one of the important waste observed in many countries) as a raw $\mathrm{Ca}^{2+}$-source material can reduce cost of calcium phosphate production [13]. Oyster, one of bivalve mollusk, can be found in the coastal area where the brine water mixes with fresh water. Thailand is one of the oyster-rich countries. Eastern and southern parts of Thailand is the most area where oysters can be found, and two most oysters' productions are Chonburi (Eastern of Thailand) and Surat Thani (Southern of Thailand). Crassostrea iredalei, Saccostrea cucullata, and Crassostrea belcheri are the three major species widely cultivated for oyster [14]. In 2019, Thailand's coastal aquaculture produced about 17,903 tonnes of the oyster [15]. The results observed in [15] reported that the major phase of raw oyster was $\mathrm{CaCO}_{3}$ (92.6 $\mathrm{wt} \%$ calcite and $2.71 \mathrm{wt} \%$ aragonite), which is the important source of calcium $\left(\mathrm{Ca}^{2+}\right)$. The X-ray fluorescence (XRF) result reported in [15] also demonstrated that the chemical composition of oyster was mostly calcium oxide $(\mathrm{CaO})(53.66$ $w t \%)$. Furthermore, oxides of silicon $\left(\mathrm{SiO}_{2}, 0.45 \mathrm{wt} \%\right)$, aluminium $\left(\mathrm{Al}_{2} \mathrm{O}_{3}, 0.12 \mathrm{wt} \%\right)$, iron $\left(\mathrm{Fe}_{2} \mathrm{O}_{3}, 0.06 \mathrm{wt} \%\right)$, magnesium $(\mathrm{MgO}, 0.26 \mathrm{wt} \%)$, potassium $\left(\mathrm{K}_{2} \mathrm{O}, 0.06 \mathrm{wt} \%\right)$, sodium $(\mathrm{Na} 2 \mathrm{O}, 0.55 \mathrm{wt} \%)$, titanium $\left(\mathrm{TiO}_{2}<0.01 \mathrm{wt} \%\right)$, manganese $(\mathrm{MnO}, 0.01 \mathrm{wt} \%)$, and phosphorous $\left(\mathrm{P}_{2} \mathrm{O}_{5}, 0.16 \mathrm{wt} \%\right)$ were also observed [15].

Consequently, the recycling of wastes (i.e., oyster) by applying as $\mathrm{Ca}^{2+}$ source is beneficial for reducing the waste and most useful for various industrial uses. The aim of this work is to recrystallize the soluble calcium phosphate $\left(\mathrm{Ca}\left(\mathrm{H}_{2} \mathrm{PO}_{4}\right)_{2} \cdot \mathrm{H}_{2} \mathrm{O}\right)$ compound from oyster-derived triple superphosphate and identify the physicochemical properties of recrystallized products by X-ray diffraction (XRD), Fourier transform infrared spectroscopy (FTIR), thermogravimetric/differential thermal analysis (TG/DTA) and scanning electron microscopy (SEM). 


\section{Materials and Methods}

\subsection{Preparation}

Oyster shell waste was used as the starting material $\left(\mathrm{CaCO}_{3}\right.$ as $\mathrm{Ca}^{2+}$ source) to prepare the triple superphosphate (TSP). After that, the oyster shell-derived TSP compound was then used as the precursor to recrystallize the $\mathrm{Ca}\left(\mathrm{H}_{2} \mathrm{PO}_{4}\right)_{2} \cdot \mathrm{H}_{2} \mathrm{O}(\mathrm{MCPM})$. Figure 1 shows the schematic diagram designed for MCPM preparation.

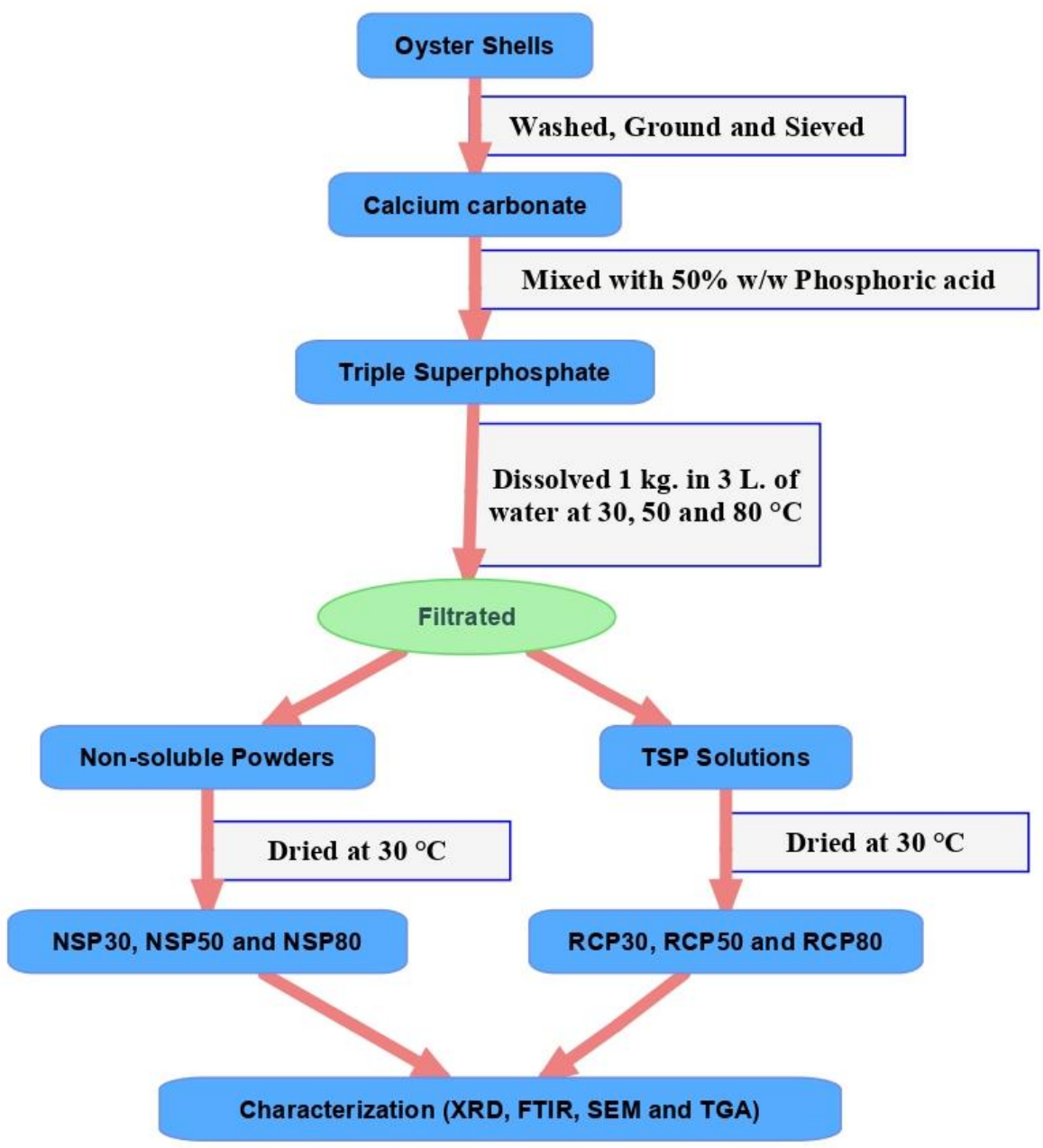

Figure 1. Schematic diagram designed for $\mathrm{Ca}\left(\mathrm{H}_{2} \mathrm{PO}_{4}\right)_{2} \cdot \mathrm{H}_{2} \mathrm{O}(\mathrm{MCPM})$ preparation by using oyster-derived TSP (triple superphosphate) as the precursor

The waste was collected from a local shellfish market in Chonburi, Thailand, and was cleaned by sodium hypochlorite $(\mathrm{NaOCl}$, saturated solution) until shell's meat were destroyed completely. The shells after cleaning process were kept at $110^{\circ} \mathrm{C}$ in an oven for 60 min. The dried shells were milled and then sieved by 100 mesh-sieve number. Using this process, approximately $140 \mu \mathrm{m}$ oyster-shell-derived $\mathrm{CaCO}_{3}$ powders were achieved and used as a raw material. A concentration of $50 \% \mathrm{w} / \mathrm{w} \mathrm{H}_{3} \mathrm{PO}_{4}$ prepared from $85 \% \mathrm{w} / \mathrm{w}$ industrial grade $\mathrm{H}_{3} \mathrm{PO}_{4}$ was also used as a reagent for the TSP preparation. The process described well by Seesanong et al. [16] was used to prepare TSP. A beaker containing $10 \mathrm{~g}$ of shell-derived $\mathrm{CaCO}_{3}$ powder was added by a volume of $13.97 \mathrm{~mL}$ of $50 \% \mathrm{w} / \mathrm{w} \mathrm{H}_{3} \mathrm{PO}_{4}$. The mixed suspension was stirred at $100 \mathrm{rpm}$ until the carbon dioxide $\left(\mathrm{CO}_{2}\right)$ gas was not evolved (approximately $30 \mathrm{~min}$ ). The product in pale yellow-white color was obtained and exposed to the ambient conditions for $12 \mathrm{~h}$ for drying process. Eq. (1) shows the chemical reaction between oyster-shell-derived $\mathrm{CaCO}_{3}$ and $\mathrm{H}_{3} \mathrm{PO}_{4}$, and TSP $\left(\mathrm{Ca}\left(\mathrm{H}_{2} \mathrm{PO}_{4}\right)_{2} \cdot \mathrm{H}_{2} \mathrm{O}\right)$ was then synthesized from this reaction.

$$
\mathrm{CaCO}_{3}(\mathrm{~s})+2 \mathrm{H}_{3} \mathrm{PO}_{4}(\mathrm{aq}) \rightarrow \mathrm{Ca}\left(\mathrm{H}_{2} \mathrm{PO}_{4}\right)_{2} \cdot \mathrm{H}_{2} \mathrm{O}(\mathrm{s})+\mathrm{CO}_{2}(\mathrm{~g})
$$


After that, $1 \mathrm{~kg}$ of synthesized TSP was then dissolved in 3L of deionized water and kept at three different temperatures, namely 30,50 , and $80^{\circ} \mathrm{C}$ for $2 \mathrm{~h}$. According to the hydrolyzed reaction (Eq. (2), TSP was dissolved, while the orthophosphoric acid $\left(\mathrm{H}_{3} \mathrm{PO}_{4}\right)$ and calcium hydrogen phosphate $\left(\mathrm{CaHPO}_{4}\right)$ species were generated from this hydrolyzed reaction, which are the intermediates used to recrystallize and obtain MCPM $\left(\mathrm{Ca}\left(\mathrm{H}_{2} \mathrm{PO}_{4}\right)_{2} \cdot \mathrm{H}_{2} \mathrm{O}\right)$.

$$
\mathrm{Ca}\left(\mathrm{H}_{2} \mathrm{PO}_{4}\right)_{2} \cdot \mathrm{H}_{2} \mathrm{O}+\mathrm{H}_{2} \mathrm{O} \leftrightarrow \mathrm{H}_{3} \mathrm{PO}_{4}+\mathrm{CaHPO}_{4}+2 \mathrm{H}_{2} \mathrm{O}
$$

However, some fraction of TSP was not dissolved in water. Therefore, the resulting solution was filtrated by filter paper using Buchner funnel with the suction system. After filtration, the non-soluble powders on the filter paper were dried at $30^{\circ} \mathrm{C}$ for $1 \mathrm{~h}$, and the non-soluble powders from the process operated at 30,50 , and $80{ }^{\circ} \mathrm{C}$ were labeled as NSP30, NSP50, and NSP80, respectively.

In case of soluble fraction, the obtained TSP solutions were kept and dried at $30^{\circ} \mathrm{C}$ for $3 \mathrm{~h}$. Using this drying process, the recrystallized $\mathrm{Ca}\left(\mathrm{H}_{2} \mathrm{PO}_{4}\right)_{2} \cdot \mathrm{H}_{2} \mathrm{O}(\mathrm{MCPM})$ products were obtained. The recrystallized products prepared at 30,50 , and $80^{\circ} \mathrm{C}$ were coded as $\mathrm{RCP} 30, \mathrm{RCP} 50$, and RCP80, respectively. The percent yields of the recrystallized products were calculated by using Eq. (3)

$$
\operatorname{Yield}(\%)=\frac{m_{\text {obs }}}{m_{\text {theor }}} \times 100
$$

when $m_{\text {obs }}$ is the mass of the synthesized $\mathrm{Ca}\left(\mathrm{H}_{2} \mathrm{PO}_{4}\right)_{2} \cdot \mathrm{H}_{2} \mathrm{O}$ powder from each recrystallized temperature and $m$ theor is the mass of the theoretical $\mathrm{Ca}\left(\mathrm{H}_{2} \mathrm{PO}_{4}\right)_{2} \cdot \mathrm{H}_{2} \mathrm{O}$ (mass before recrystallization process).

\subsection{Characterization}

Dried powder of the recrystallized product was then ground by ball mill technique for $15 \mathrm{~min}$ at ambient temperature. The solubility performance of the recrystallized samples was determined by added $1 \mathrm{~g}$ of sample into $100 \mathrm{~mL}$ of deionized water with stirring mode at $60 \mathrm{rpm}$ for $1 \mathrm{~h}$. The resulting mixture was then filtrated by Buchner funnel, dried at $60^{\circ} \mathrm{C}$ for $6 \mathrm{~h}$ and then weighted to determine the solubility value of the recrystallized samples.

The non-soluble powders (NSP30, NSP50, and NSP80) and the recrystallized products (RCP30, RCP50, and RCP80) were characterized by X-ray powder diffractometer (XRD, D8 Advance, Bruker AXS, Karlsruhe) to identify the structure, purity, and the crystallinity of the prepared samples. Two theta $(2 \theta)$ angles ranged from $5^{\circ}$ to $60^{\circ}$ with the $\mathrm{Cu}$ $K_{\alpha} X$-ray source. $1 \mathrm{~s}$ per step was selected as the scan speed of the test at $0.01^{\circ}$ increment. The Joint Committee on Powder Diffraction Standards (JCPDS) database was used to compare and confirm the crystal structure and purity of samples obtained from experimental XRD results. Surface morphologies of samples were observed by scanning electron microscope (SEM, VPI450 LEO) with energy dispersive X-ray (EDX) mode. This EDX technique was used to evaluate the elemental compositions of samples. The gold-coated technique was used for sample preparation [17]. Infrared adsorption spectra were recorded on the Fourier transform infrared spectrophotometer (FTIR, Spectrum GX, Perkin Elmer). The measurement range is between 4000 and $370 \mathrm{~cm}^{-1}$. A resolution of $2 \mathrm{~cm}^{-1}$ was selected with 32 scans to decrease the noise signal [18]. To prepare the infrared adsorption sample, each non-soluble (NSP30, NSP50, and NSP80) and recrystallized (RCP30, RCP50, and RCP80) product was homogeneously mixed with the potassium bromide $(\mathrm{KBr}$, spectroscopic grade) powder at the mass ratio of 1:10 [19]. The obtained mixture was compressed into a small pellet form using manual hydraulic press and then placed inside a sample holder of 
the infrared spectrophotometer [20]. Thermal decomposition behavior of the recrystallized samples was analyzed by thermogravimetric/differential thermal analysis (TG/DTA, Pyris Diamond, Perkin Elmer) instrument. The decomposition characteristics of the recrystallized samples was observed from the obtained TG/DTA profiles at a heating rate of $10{ }^{\circ} \mathrm{C} \cdot \mathrm{min}^{-1}$ from room temperature to $800{ }^{\circ} \mathrm{C}$ under the inert $\left(\mathrm{N}_{2}\right)$ gas at a flow rate of 80 $\mathrm{mL} \cdot \mathrm{min}^{-1}$. The sample powder was loaded into an alumina pan without a lid and pressing process using the calcined $\alpha-\mathrm{Al}_{2} \mathrm{O}_{3}$ as the reference material [21].

\section{Results and Discussion}

\subsection{Yield and soluble percentage}

Masses ( $\mathrm{g}$ ) of recrystallized products, their corresponding yields (\%), and the solubility values (\%) were investigated and the results are shown in Table 1 . Using $10 \mathrm{~g}$ of shell-derived TSP, $5.10,4.96$, and $4.63 \mathrm{~g}$ of recrystallized $\mathrm{Ca}\left(\mathrm{H}_{2} \mathrm{PO}_{4}\right)_{2} \cdot \mathrm{H}_{2} \mathrm{O}$ products were obtained for RCP30, RCP50, and RCP80, respectively. The obtained masses of the products indicated that the yields of the product obtained from the recrystallization process (Table 1) decreased with increasing temperature that used to dissolve the TSP, and the product obtained from the dissolved temperature of $30^{\circ} \mathrm{C}$ showed the highest recrystallized yield $(51.0 \%)$. After that, the solubility of recrystallized products was investigated. Form the experimental results, the solubilities of RCP30 and RCP50 are $98.72 \%$ and $99.16 \%$ respectively, whereas the solubility of RCP80 $(96.63 \%)$ is significantly lower than other samples. According to the previous research, it was reported that the solubility of efficient TSP fertilizer $\left[\mathrm{Ca}\left(\mathrm{H}_{2} \mathrm{PO}_{4}\right)_{2} \cdot \mathrm{H}_{2} \mathrm{O}\right]$ is usually more than $85 \%$ [22]. This solubility performance is dependent on the fertilizers' sources (i.e., reactant grade used for $\mathrm{Ca}\left(\mathrm{H}_{2} \mathrm{PO}_{4}\right)_{2} \cdot \mathrm{H}_{2} \mathrm{O}$ preparation) and the operating conditions (i.e., neutral or basic or acidic condition). Consequently, this observation indicated that all recrystallized $\mathrm{Ca}\left(\mathrm{H}_{2} \mathrm{PO}_{4}\right)_{2} \cdot \mathrm{H}_{2} \mathrm{O}$ obtained in this research are the excellent soluble fertilizers for the agronomic performance. Additionally, the solubility of the product recrystallized at low dissolved temperature is higher than that the product recrystallized at higher dissolved temperature, and $50{ }^{\circ} \mathrm{C}$ is the suitable dissolved temperature to recrystallize the soluble $\mathrm{Ca}\left(\mathrm{H}_{2} \mathrm{PO}_{4}\right)_{2} \cdot \mathrm{H}_{2} \mathrm{O}$ fertilizer.

Table 1. Mass of recrystallized products, recrystallized yield, and soluble fraction percentage obtained from $\mathrm{Ca}\left(\mathrm{H}_{2} \mathrm{PO}_{4}\right) 2 \cdot \mathrm{H}_{2} \mathrm{O}$ samples

\begin{tabular}{cccc}
\hline Samples & Masses of products (from 10 g TSP)/g & Yields/\% & Solubilities/\% \\
\hline RCP30 & 5.10 & 51.0 & 98.72 \\
RCP50 & 4.96 & 49.6 & 99.16 \\
RCP80 & 4.63 & 46.3 & 96.63 \\
\hline
\end{tabular}

When pure $\mathrm{Ca}\left(\mathrm{H}_{2} \mathrm{PO}_{4}\right)_{2} \cdot \mathrm{H}_{2} \mathrm{O}$ phase is dissolved in water medium, $\mathrm{H}_{3} \mathrm{PO}_{4}$ and $\mathrm{CaHPO}_{4}$ species were formed [7] according to hydrolyzed reaction as shown in Eq. (2). However, the reactions did not complete because the acid $\left(\mathrm{H}_{3} \mathrm{PO}_{4}\right)$ did not remove from the system [7]. Therefore, the solution system without the addition of other chemical reagents such as basic reagent, especially sodium hydroxide $(\mathrm{NaOH})$, the equilibrium phenomenon will be obtained, and the $\mathrm{H}_{3} \mathrm{PO}_{4}$ will remain between amorphous $\mathrm{CaHPO}_{4}$ and crystalline $\mathrm{Ca}\left(\mathrm{H}_{2} \mathrm{PO}_{4}\right)_{2} \cdot \mathrm{H}_{2} \mathrm{O}$. Therefore, when the $\mathrm{Ca}\left(\mathrm{H}_{2} \mathrm{PO}_{4}\right)_{2} \cdot \mathrm{H}_{2} \mathrm{O}$ product, recrystallized from $\mathrm{Ca}^{2+}-$ 
rich oyster waste TSP, was employed as the fertilizer, the largest amount of phosphorus content with the lowest impurities will be valuable for cultivation process.

\subsection{Morphology and chemical composition (SEM-EDX)}

SEM technique was applied to observe the morphological characteristics of the recrystallized samples. SEM images of RCP30, RCP50, and RCP80 products are shown in Figure 2. The micrograph of RCP30 (Figure 2a) shows many plates of crystal intersperse in different sizes. Whereas the morphologies of RCP50 (Figure 2b) and RCP80 (Figure 2c) products present the coagulate plate of crystals. According to the SEM results, it can be seen that the crystal size of RCP80 is smaller than that of the crystal size of RCP50. Using the EDX analysis, that coupled to SEM technique, the elemental composition was investigated, and the EDX result as demonstrated in Table 2 indicates the presences of calcium $\mathrm{Ca}$, phosphorous $\mathrm{P}$, and oxygen O elements, which is characteristic of the $\mathrm{Ca}\left(\mathrm{H}_{2} \mathrm{PO}_{4}\right)_{2} \cdot \mathrm{H}_{2} \mathrm{O}$ recrystallized in the present work. Furthermore, the results of EDX show the presences of potassium $\mathrm{K}$ and aluminium $\mathrm{Al}$ elements (slightly amount) as the adulterate ions.
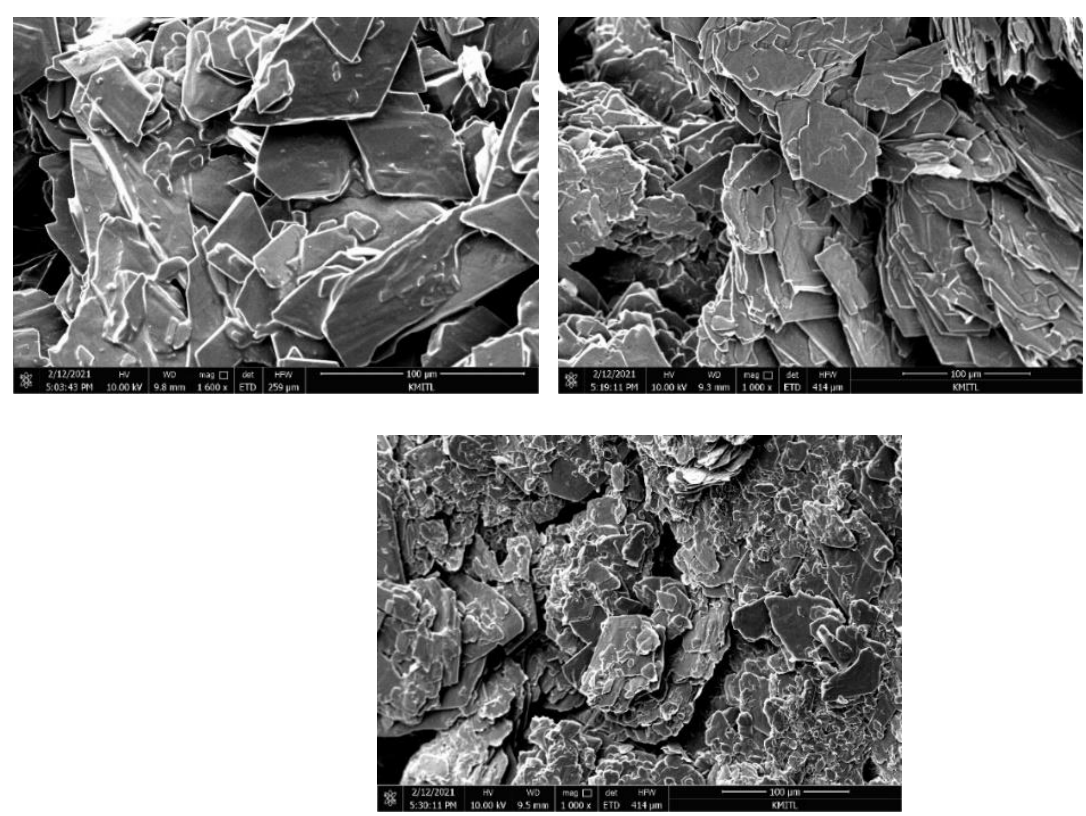

Figure 2. Morphological characteristics (scanning electron microscopic (SEM) images by using goldcoating technique for sample preparation) of $\mathrm{Ca}\left(\mathrm{H}_{2} \mathrm{PO}_{4}\right)_{2} \cdot \mathrm{H}_{2} \mathrm{O}$ products recrystallized after dissolving TSP at $30{ }^{\circ} \mathrm{C}\left[R C P 30\right.$ (a)], $50{ }^{\circ} \mathrm{C}\left[R C P 50\right.$ (b)], and $80{ }^{\circ} \mathrm{C}$ [RCP80 (c)]

\section{3. $X$-ray diffractogram $(X R D)$}

D8 Advance XRD was employed to determine the diffraction pattern of the samples obtained from both non-soluble powders and the recrystallized products. The X-ray diffractograms (or XRD patterns) of NSP30, NSP50, and NSP80 samples are displayed in Figure 3 . The diffractogram results indicated that all peaks present the diffraction characteristic of $\mathrm{CaHPO}_{4} \cdot 2 \mathrm{H}_{2} \mathrm{O}$ based on the standard JCPDS \# 72-0713 [23]. From the previous work, the lattice parameters of $\mathrm{CaHPO}_{4} \cdot 2 \mathrm{H}_{2} \mathrm{O}$ are $a=5.812, b=15.180, c=6.239 \AA$ with the monoclinic crystal system and space group of $I a$, whereas the $\beta$ angle equals to $116.42^{\circ}$ [24]. Its structural layers are comprised of $\mathrm{PO}_{4}$ tetrahedra and $\mathrm{CaO}_{8}$ octahedra. Six $\mathrm{O}$ atoms of $\mathrm{CaO}_{8}$ are bound to $\mathrm{PO}_{4}$, and other two $\mathrm{O}$ atoms of $\mathrm{CaO} 8$ belong to $\mathrm{H}_{2} \mathrm{O}$ [25]. The $\mathrm{H}$ is 
bound to the $\mathrm{O}$ atom with the longest $\mathrm{P}-\mathrm{O}$ bond in the $\mathrm{PO}_{4}$ [26]. Layers within Ca$\mathrm{HPO}_{4} \cdot 2 \mathrm{H}_{2} \mathrm{O}$ are held together by $\mathrm{H}$ bonds and are parallel to the $c$-axis [27]. The $\mathrm{H}$ in the two $\mathrm{H}_{2} \mathrm{O}$ forms strong bonds with $\mathrm{O}$ of $\mathrm{PO}_{4}$; weak $\mathrm{H}$ bonds exist between $\mathrm{O}$ of $\mathrm{H}_{2} \mathrm{O}$ and $\mathrm{H}$ of $\mathrm{P}-\mathrm{OH}$, and, also, between the molecules of $\mathrm{H}_{2} \mathrm{O}$ [28]. The molecules of $\mathrm{H}_{2} \mathrm{O}$ in Ca$\mathrm{HPO}_{4} \cdot 2 \mathrm{H}_{2} \mathrm{O}$ are not identical, and the $\mathrm{H}-\mathrm{O}-\mathrm{H}$ bond angles of $105.4^{\circ}$ and $106.6^{\circ}$ were reported by Schofield et al. [25] and Curry and Jones [26]. Furthermore, one molecule of $\mathrm{H}_{2} \mathrm{O}$ had the $\mathrm{H}$-bond angles of $167.3^{\circ}$ and $165.8^{\circ}$ and another molecule had the angles of $175.7^{\circ}$ and $173.3^{\circ}[26]$.

Table 2. Chemical elements observed from energy dispersive X-ray (EDX) data of $\mathrm{Ca}\left(\mathrm{H}_{2} \mathrm{PO}_{4}\right)_{2} \cdot \mathrm{H}_{2} \mathrm{O}$ recrystallized from oyster-shell-waste TSP samples

\begin{tabular}{cccc}
\hline Elements & RCP30 & RCP50 & RCP80 \\
\hline Carbon, C & 8.88 & 12.75 & 15.08 \\
Oxygen, O & 55.40 & 47.13 & 48.73 \\
Phosphorous, P & 21.85 & 23.33 & 20.54 \\
Aluminium, Al & - & 0.45 & 1.24 \\
Potassium, K & 0.87 & 1.91 & 1.90 \\
Calcium, Ca & 13.01 & 14.43 & 12.51 \\
Total & $\mathbf{1 0 0 . 0 0}$ & $\mathbf{1 0 0 . 0 0}$ & $\mathbf{1 0 0 . 0 0}$ \\
\hline
\end{tabular}

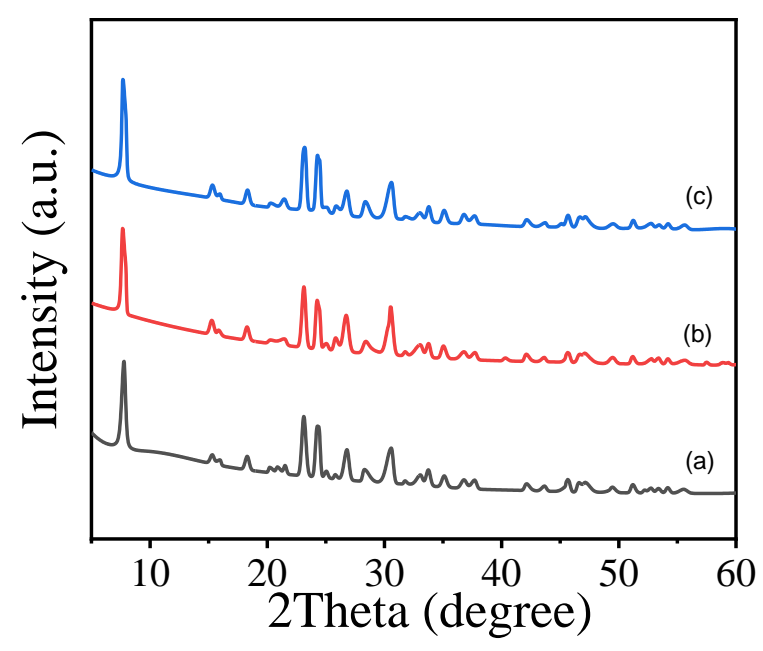

Figure 3. $\mathrm{X}$-ray diffraction (XRD) patterns of non-soluble $\mathrm{CaHPO}_{4} \cdot 2 \mathrm{H}_{2} \mathrm{O}$ products (NSP30 (a), NSP50 (b), and NSP80 (c)) obtained from in the $2 \theta$ range of $5^{\circ}-60^{\circ}$

Figure 4 shows the XRD patterns of recrystallized products (RCP30, RCP50, and RCP80). The peaks with the highest intensities (in $2 \theta$ ) are observed around $7.8^{\circ}, 15.4^{\circ}$, $23.1^{\circ}, 24.4^{\circ}, 30.7^{\circ}$, and $46.6^{\circ}$. The XRD pattern results indicate and confirm the formation of calcium dihydrogen phosphate monohydrate $\left[\mathrm{Ca}\left(\mathrm{H}_{2} \mathrm{PO}_{4}\right)_{2} \cdot \mathrm{H}_{2} \mathrm{O}\right]$ according to the JCPDF \# 009-0347, which can be applied as a nutrient, yeast food, leavening agent, hardener, and as a buffer [3]. According to the previous work, it was reported that $\mathrm{Ca}\left(\mathrm{H}_{2} \mathrm{PO}_{4}\right)_{2} \cdot \mathrm{H}_{2} \mathrm{O}$ crystallizes in a triclinic crystal system, and the lattice parameters are $a=$ $6.25 \AA, b=11.89 \AA$, and $c=5.63 \AA$ with and $\alpha=96.67^{\circ}, \beta=114.20^{\circ}$, and $\gamma=92.95^{\circ}$ [3]. The crystal structure of $\mathrm{Ca}\left(\mathrm{H}_{2} \mathrm{PO}_{4}\right)_{2} \cdot \mathrm{H}_{2} \mathrm{O}$ was well described by Dickens and Bowen [29]. The chains of $\mathrm{CaH}_{2} \mathrm{PO}_{4}{ }^{+}$form corrugated layers. The layers of $\mathrm{H}_{2} \mathrm{PO}_{4}^{-}$and $\mathrm{H}_{2} \mathrm{O}$ were observed in the layers between $\mathrm{CaH}_{2} \mathrm{PO}_{4}{ }^{+}$layers. The positions of two $\mathrm{H}$ sets differ by $\sim 0.28 \AA$. One $\mathrm{H}$ bond of $\mathrm{H}_{2} \mathrm{O}$-donor molecule is apparently bifurcated. Whereas other $\mathrm{H}$ atoms form normal $\mathrm{H}$ bonds, and each site of $\mathrm{H}$ atoms was fully occupied [29]. Furthermore, the diffractogram of RCP80 also indicates some residues at $10.26^{\circ}$, which can be attributed to 
hydrogenated hydrated calcium chloride $\left(\mathrm{CaClH}_{2} \mathrm{PO}_{4} \cdot \mathrm{H}_{2} \mathrm{O}\right)$ [3] according to the JCPDF \# 044-000746.

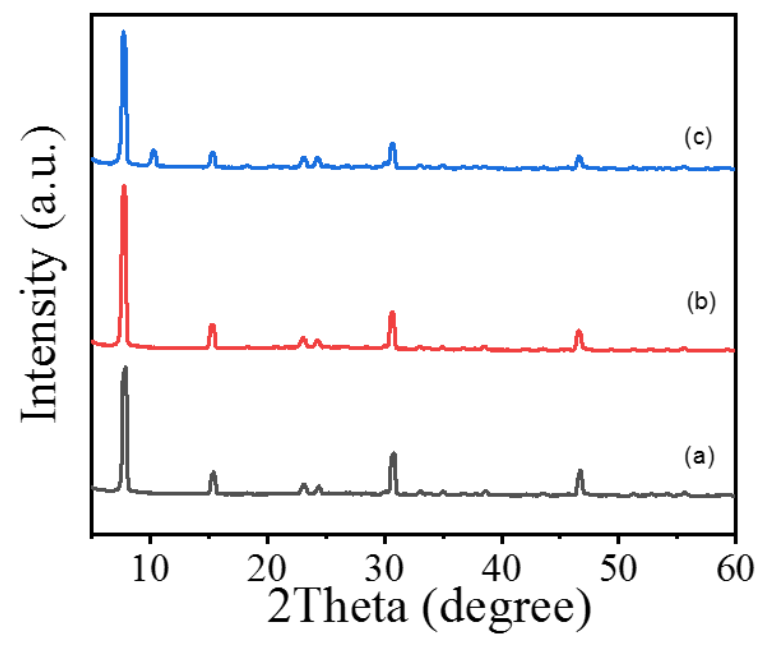

Figure 4. X-ray diffraction (XRD) patterns in the $2 \theta$ range of $5^{\circ}-60^{\circ}$ of the recrystallized $\mathrm{Ca}\left(\mathrm{H}_{2} \mathrm{PO}_{4}\right)_{2} \cdot \mathrm{H}_{2} \mathrm{O}$ products after dissolving TSP at $30{ }^{\circ} \mathrm{C}\left[\mathrm{RCP} 30\right.$ (a)], $50{ }^{\circ} \mathrm{C}\left[\mathrm{RCP} 50\right.$ (b)], and $80{ }^{\circ} \mathrm{C}$ [RCP80 (c)]

\subsection{Vibrational spectroscopy (FTIR)}

Infrared adsorptions of non-soluble powders (NSP30, NSP50, and NSP80) are recorded by Spectrum GX FTIR spectrophotometer, and the resulting spectra are shown in Figure 5. Infrared adsorption frequencies of non-soluble powders are in line with results reported by Tortet et al. [30] and Dosen and Giese [27]. The vibrational characteristics of hydrogen phosphate anion $\left(\mathrm{HPO}_{4}{ }^{2-}\right)$ and water $\left(\mathrm{H}_{2} \mathrm{O}\right)$ molecule were used to explain the infrared spectra obtained in the present work. The vibrational characteristic modes, sort from high wavenumber $\left(\mathrm{cm}^{-1}\right)$ to low wavenumber, consisted of $\mathrm{O}-\mathrm{H}$ stretching of absorbed $\mathrm{H}_{2} \mathrm{O}, \mathrm{O}-\mathrm{H}$ stretching of $\mathrm{OH}-$ ion in $\mathrm{HPO}_{4}{ }^{2-},(\mathrm{P}) \mathrm{O}-\mathrm{H}$ stretching of $\mathrm{HPO}_{4}{ }^{2-}, \mathrm{H}-\mathrm{O}-\mathrm{H}$ bending and rotation of $\mathrm{H}_{2} \mathrm{O}, \mathrm{H}-\mathrm{O}-\mathrm{H}$ bending of $\mathrm{H}_{2} \mathrm{O}$, very low $\mathrm{H}-\mathrm{O}-\mathrm{H}$ bending of $\mathrm{H}_{2} \mathrm{O}$, $\mathrm{P}-\mathrm{O}-\mathrm{H}$ in-plane-bending of $\mathrm{HPO}_{4}{ }^{2-}, \mathrm{P}-\mathrm{O}$ stretching of $\mathrm{HPO}_{4}{ }^{2-}, \mathrm{P}-\mathrm{O}(\mathrm{H})$ stretching of $\mathrm{HPO}_{4}{ }^{2-}$, absorbed $\mathrm{H}_{2} \mathrm{O}$, and $\mathrm{O}-\mathrm{P}-\mathrm{O}(\mathrm{H})$ bending of $\mathrm{HPO}_{4}{ }^{2-}$, respectively. Table 3 summaries the vibrational modes and their corresponding wavenumbers obtained in this research. According to the obtained results, it was confirmed that $\mathrm{CaHPO}_{4} \cdot 2 \mathrm{H}_{2} \mathrm{O}$ is the compound found in the non-soluble powder.

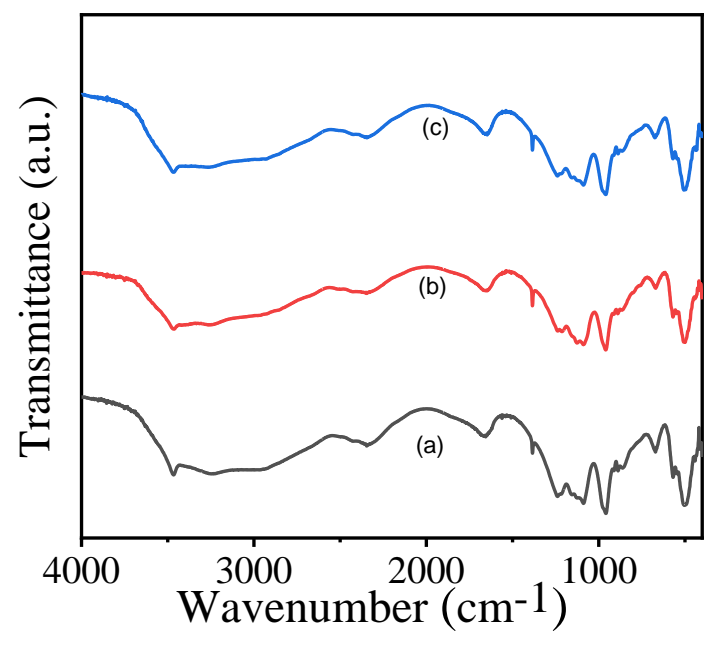

Figure 5. Infrared adsorption (FTIR) spectra of non-soluble $\mathrm{CaHPO}_{4} \cdot 2 \mathrm{H}_{2} \mathrm{O}$ products obtained from $30{ }^{\circ} \mathrm{C}[\mathrm{NSP} 30(\mathrm{a})], 50^{\circ} \mathrm{C}\left[\mathrm{NSP} 50\right.$ (b)], and $80^{\circ} \mathrm{C}$ [NSP80 (c)] in the wavenumber from $4000-370 \mathrm{~cm}^{-1}$ 
Infrared adsorptions of the recrystallized products (RCP30, RCP50, and RCP80) are shown in Figure 6. By comparison, it is realized that the spectra of RCP30, RCP50, and RCP80 samples are similar. The obtained infrared spectra are mainly characterized based on the vibrational characteristics of dihydrogen phosphate anion $\left(\mathrm{H}_{2} \mathrm{PO}_{4}{ }^{-}\right)$and water $\left(\mathrm{H}_{2} \mathrm{O}\right)$ molecule. The vibrational characteristic modes consisted of $\mathrm{O}-\mathrm{H}$ stretching of absorbed $\mathrm{H}_{2} \mathrm{O}$, O- $\mathrm{O}$ stretching of $\mathrm{OH}^{-}$ion in $\mathrm{H}_{2} \mathrm{PO}_{4}^{-},(\mathrm{P}) \mathrm{O}-\mathrm{H}$ stretching of $\mathrm{H}_{2} \mathrm{PO}_{4}^{-}, \mathrm{H}-\mathrm{O}-\mathrm{H}$ bending and rotation of $\mathrm{H}_{2} \mathrm{O}, \mathrm{H}-\mathrm{O}-\mathrm{H}$ bending of $\mathrm{H}_{2} \mathrm{O}, \mathrm{P}-\mathrm{O}-\mathrm{H}$ in-plane-bending of $\mathrm{H}_{2} \mathrm{PO}_{4}^{-}$ , $\mathrm{P}-\mathrm{O}$ stretching of $\mathrm{H}_{2} \mathrm{PO}_{4}{ }^{-}, \mathrm{P}-\mathrm{O}(\mathrm{H})$ stretching of $\mathrm{H}_{2} \mathrm{PO}_{4^{-}}$, absorbed $\mathrm{H}_{2} \mathrm{O}$, and $\mathrm{O}-\mathrm{P}-\mathrm{O}(\mathrm{H})$ bending of $\mathrm{H}_{2} \mathrm{PO}_{4}^{-}$, respectively. Their wavenumbers are shown in Table 3. Experimental results obtained in this research tally to the results reported in the literatures [31-33]. The wavenumber at 669-676, 888-889, 964-980, 1080-1095, and 1231-1240 $\mathrm{cm}^{-1}$, as demonstrated in Table 3, are the main five vibrational characteristics of $\mathrm{Ca}\left(\mathrm{H}_{2} \mathrm{PO}_{4}\right)_{2} \cdot \mathrm{H}_{2} \mathrm{O}$. Consequently, the vibrational characteristics obtained in the present work correspond and confirm the formation of MCPM or $\mathrm{Ca}\left(\mathrm{H}_{2} \mathrm{PO}_{4}\right)_{2} \cdot \mathrm{H}_{2} \mathrm{O}$ that recrystallized from oyster-shell-waste derived TSP.

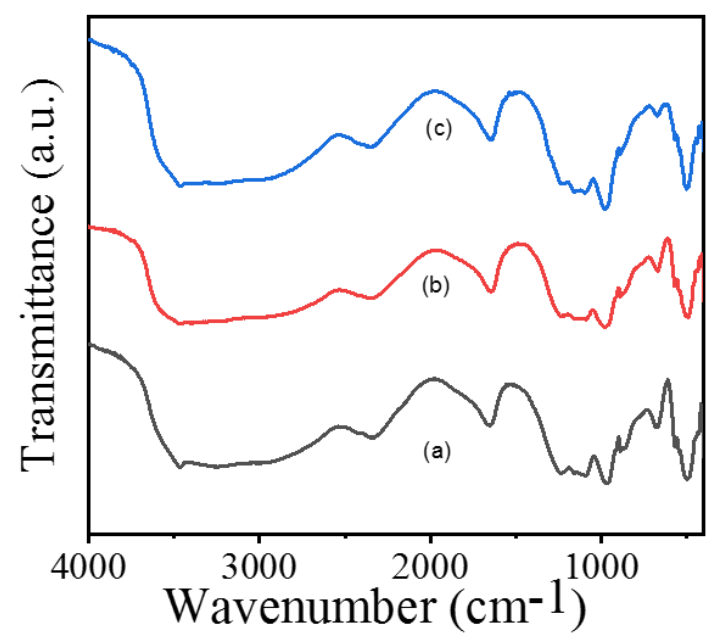

Figure 6. Infrared adsorption (FTIR) spectra of the recrystallized $\mathrm{Ca}\left(\mathrm{H}_{2} \mathrm{PO}_{4}\right)_{2} \cdot \mathrm{H}_{2} \mathrm{O}$ products after dissolving TSP at $30^{\circ} \mathrm{C}\left[\mathrm{RCP} 30\right.$ (a)], $50{ }^{\circ} \mathrm{C}\left[\mathrm{RCP} 50\right.$ (b)], and $80{ }^{\circ} \mathrm{C}[\mathrm{RCP} 80$ (c)] in the wavenumber from $4000-370 \mathrm{~cm}^{-1}$

Table 3. Vibrational characteristics (modes) and vibrational positions (wavenumbers $/ \mathrm{cm}^{-1}$ ) observed in the non-soluble $\mathrm{CaHPO}_{4} \cdot 2 \mathrm{H}_{2} \mathrm{O}$ (NSP30, NSP50, NSP80) and the recrystallized $\mathrm{Ca}\left(\mathrm{H}_{2} \mathrm{PO}_{4}\right)_{2} \cdot \mathrm{H}_{2} \mathrm{O}(\mathrm{RCP} 30, \mathrm{RSP} 50, \mathrm{RCP} 80)$ compounds

\begin{tabular}{|c|c|c|c|c|c|c|}
\hline \multirow[t]{3}{*}{ Vibration modes } & \multicolumn{6}{|c|}{ Wavenumber $\left(/ \mathrm{cm}^{-1}\right)$ of } \\
\hline & \multicolumn{3}{|c|}{ Non-soluble $\mathrm{CaHPO}_{4} \cdot 2 \mathrm{H}_{2} \mathrm{O}$ products } & \multicolumn{3}{|c|}{ Recrystallized $\mathrm{Ca}\left(\mathrm{H}_{2} \mathrm{PO}_{4}\right)_{2} \cdot \mathrm{H}_{2} \mathrm{O}$ products } \\
\hline & NSP30 & NSP50 & NSP80 & RCP30 & RCP50 & RCP80 \\
\hline $\mathrm{O}-\mathrm{H}$ stretching of absorbed $\mathrm{H}_{2} \mathrm{O}$ & 3466 & 3462 & 3465 & 3467 & 3466 & 3462 \\
\hline $\begin{array}{l}\mathrm{O}-\mathrm{H} \text { stretching of } \mathrm{OH}^{-} \text {ion in } \mathrm{HPO}_{4}^{2-} \text { or } \\
\mathrm{H}_{2} \mathrm{PO}_{4}^{-}\end{array}$ & 3244 & 3264 & 3260 & 3248 & 3256 & 3238 \\
\hline$(\mathrm{P}) \mathrm{O}-\mathrm{H}$ stretching of $\mathrm{HPO}_{4}{ }^{2-}$ or $\mathrm{H}_{2} \mathrm{PO}_{4}^{-}$ & 2970 & 2978 & 2972 & 3006 & 3052 & 3026 \\
\hline $\mathrm{H}-\mathrm{O}-\mathrm{H}$ bending and rotation of $\mathrm{H}_{2} \mathrm{O}$ & 2346 & 2346 & 2345 & 2346 & 2346 & 2342 \\
\hline $\mathrm{H}-\mathrm{O}-\mathrm{H}$ bending of $\mathrm{H}_{2} \mathrm{O}$ & 1656 & 1647 & 1647 & 1656 & 1642 & 1650 \\
\hline Very low $\mathrm{H}-\mathrm{O}-\mathrm{H}$ bending of $\mathrm{H}_{2} \mathrm{O}$ & 1384 & 1385 & 1385 & - & - & - \\
\hline$\underline{\mathrm{P}-\mathrm{O}-\mathrm{H} \text { in-plane-bending of } \mathrm{HPO}_{4}{ }^{2-} \text { or } \mathrm{H}_{2} \mathrm{PO}_{4}^{-}}$ & 1239 & 1238 & 1240 & 1240 & 1235 & 1231 \\
\hline 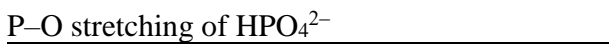 & $1155-958$ & $1155-959$ & $1155-959$ & $1159-964$ & $1166-980$ & $1159-978$ \\
\hline $\mathrm{P}-\mathrm{O}(\mathrm{H})$ stretching of $\mathrm{HPO}_{4}{ }^{2-}$ or $\mathrm{H}_{2} \mathrm{PO}_{4}^{-}$ & 888 & 890 & 888 & 888 & 888 & 889 \\
\hline Absorbed $\mathrm{H}_{2} \mathrm{O}$ & 671 & 670 & 675 & 676 & 669 & 670 \\
\hline $\mathrm{O}-\mathrm{P}-\mathrm{O}(\mathrm{H})$ bending of $\mathrm{HPO}_{4}{ }^{2-}$ or $\mathrm{H}_{2} \mathrm{PO}_{4}^{-}$ & $569-503$ & $570-499$ & $570-506$ & $570-496$ & $571-492$ & $570-504$ \\
\hline
\end{tabular}




\subsection{Thermal analysis (TG/DTA)}

The thermal decomposition behaviors of RCP30, RCP50, and RCP80 samples recorded by Pyris Diamond TG/DTA are shown in Figures $7 \mathrm{a}, 7 \mathrm{~b}$, and $7 \mathrm{c}$, respectively. The existence of the endothermic peaks located under $200{ }^{\circ} \mathrm{C}$ is identified to the loss of physisorbed water [first dehydration, Eq. (4)] on the surface of samples, resulting the formation of calcium dihydrogen phosphate anhydrous $\left[\mathrm{Ca}\left(\mathrm{H}_{2} \mathrm{PO}_{4}\right)_{2}\right]$. The endothermic phenomenon, occurred at the temperatures of $234^{\circ} \mathrm{C}$ (Figures $7 \mathrm{a}$ and $7 \mathrm{~b}$ ) and $258{ }^{\circ} \mathrm{C}$ (Figure $7 \mathrm{c}$ ), which are related to the dehydroxylation characteristic [polycondensation (orthophosphate $\mathrm{PO}_{4}{ }^{3-} \rightarrow$ pyrophosphate $\mathrm{P}_{2} \mathrm{O}_{7}{ }^{4-}$ ), second dehydration, Eq. (5)] of $\mathrm{Ca}\left(\mathrm{H}_{2} \mathrm{PO}_{4}\right)_{2}$ to form calcium dihydrogen pyrophosphate anhydrous $\left[\mathrm{CaH}_{2} \mathrm{P}_{2} \mathrm{O}_{7}\right]$. Another thermal behavior above $320{ }^{\circ} \mathrm{C}$ is the re-polycondensation (pyrophosphate $\mathrm{P}_{2} \mathrm{O}_{7}{ }^{4-} \rightarrow$ metaphosphate $\mathrm{P}_{2} \mathrm{O}_{6}{ }^{2-}$ ) process (third dehydration, Eq. (6)), which corresponds to the formation of calcium metaphosphate anhydrous $\left(\mathrm{CaP}_{2} \mathrm{O}_{6}\right)[34,35]$. Consequently, the thermal decomposition equations of the recrystallized $\mathrm{Ca}\left(\mathrm{H}_{2} \mathrm{PO}_{4}\right)_{2} \cdot \mathrm{H}_{2} \mathrm{O}$ product are shown below:

First dehydration of physisorbed water

$$
\mathrm{Ca}\left(\mathrm{H}_{2} \mathrm{PO}_{4}\right)_{2} \cdot \mathrm{H}_{2} \mathrm{O}(\mathrm{s}) \rightarrow \mathrm{Ca}\left(\mathrm{H}_{2} \mathrm{PO}_{4}\right)_{2}(\mathrm{~s})+\mathrm{H}_{2} \mathrm{O}(\mathrm{g})
$$

Second dehydration of polycondensation

$$
\mathrm{Ca}\left(\mathrm{H}_{2} \mathrm{PO}_{4}\right)_{2}(\mathrm{~s}) \rightarrow \mathrm{CaH}_{2} \mathrm{P}_{2} \mathrm{O}_{7}(\mathrm{~s})+\mathrm{H}_{2} \mathrm{O}(\mathrm{g})
$$

Third dehydration of re-polycondensation

$$
\mathrm{CaH}_{2} \mathrm{P}_{2} \mathrm{O}_{7}(\mathrm{~s}) \rightarrow \mathrm{CaP}_{2} \mathrm{O}_{6}(\mathrm{~s})+\mathrm{H}_{2} \mathrm{O}(\mathrm{g})
$$
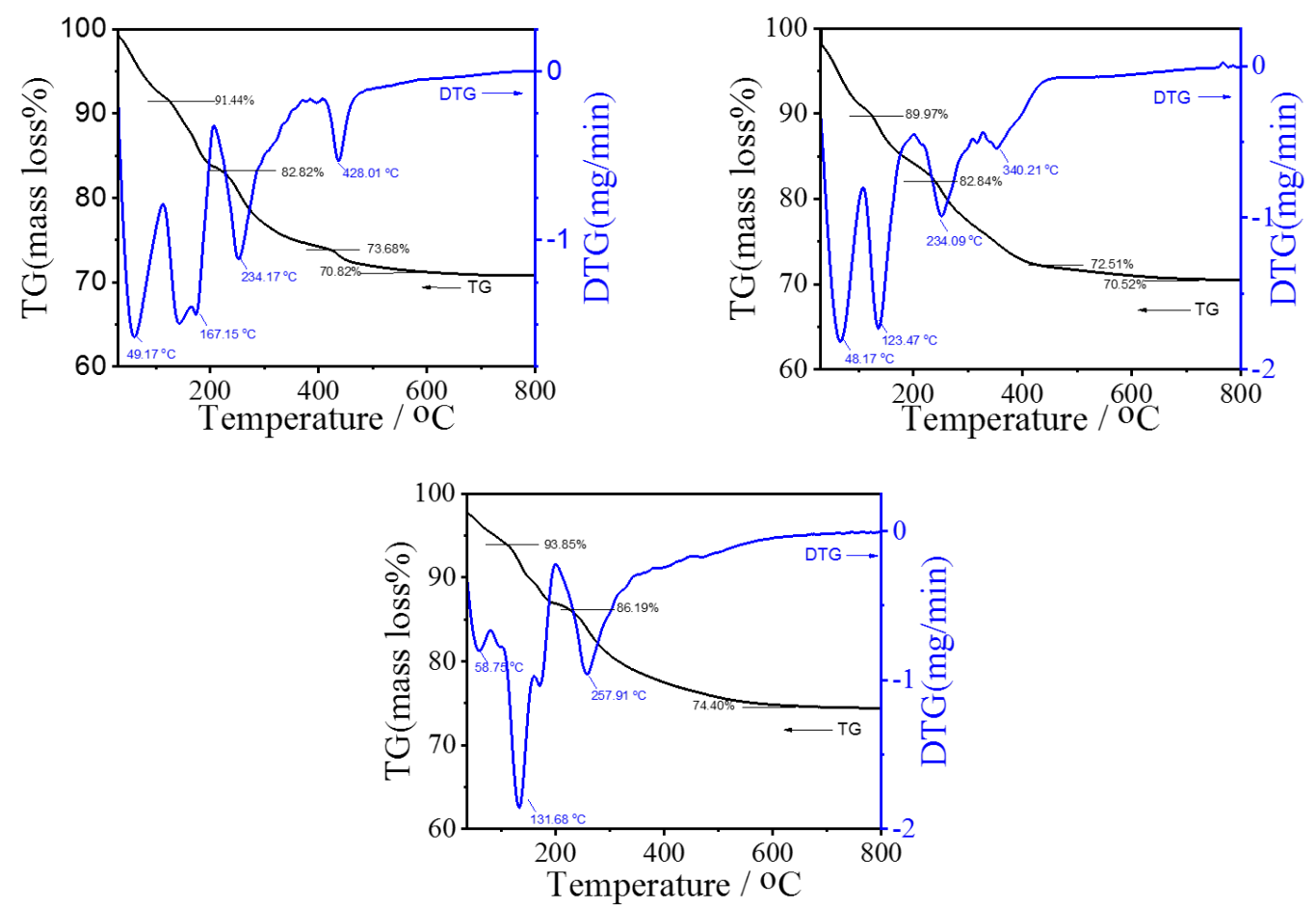

Figure 7. Thermal decomposition behaviors (TG/DTA thermograms) of RCP30 (a), RCP50 (b), and RCP80 (c) obtained from room temperature to $800{ }^{\circ} \mathrm{C}$

Some calcium phosphate compounds show safety and biological compatibility in organism tissues [34], and $\mathrm{CaP}_{2} \mathrm{O}_{6}$, one of the phosphate-based compounds, with a good 
biocompatibility property was used in biomedical fields [34]. Its mechanical values, i.e., high bending strength ( 200 Mpa) and low elastic modulus ( $\sim 5 \mathrm{GPa})$, are like to the natural cortical bone [35]. $\mathrm{CaP}_{2} \mathrm{O}_{6}$ composed a large porosity $(\sim 70 \%)$, indicating that $\mathrm{CaP}_{2} \mathrm{O}_{6}$ with the flexibility and high-strength properties can be applied as fillers to repair the bone [34]. When it is implanted in bone tissues, the spaces between tissues are filled. The fillers would be embedded by the high-convoluted growth of natural bone into the spaces. Therefore, it can be concluded that the final thermal decomposition product $\left(\mathrm{CaP}_{2} \mathrm{O}_{6}\right)$ of the recrystallized $\mathrm{Ca}\left(\mathrm{H}_{2} \mathrm{PO}_{4}\right)_{2} \cdot \mathrm{H}_{2} \mathrm{O}$ compound obtained in this work can further be applied as the biocompatible material for the biomedical fields.

\section{Conclusions}

The recrystallization process was used to prepare the well-soluble $\mathrm{Ca}\left(\mathrm{H}_{2} \mathrm{PO}_{4}\right)_{2} \cdot \mathrm{H}_{2} \mathrm{O}$ fertilizer by using the synthesized triple superphosphate (TSP) as the precursor, whereas the oyster-shell-waste-derived $\mathrm{CaCO}_{3}$ was used as raw material for TSP preparation. Using this recrystallized technique, the waste was transformed to the valuable material. Under three different dissolved temperatures, RCP30, RCP50, and RCP80 $\left[\mathrm{Ca}\left(\mathrm{H}_{2} \mathrm{PO}_{4}\right)_{2} \cdot \mathrm{H}_{2} \mathrm{O}\right]$ were obtained. The non-soluble products, namely NSP30, NSP50, and NSP80, were also investigated and observed as $\mathrm{CaHPO}_{4} \cdot 2 \mathrm{H}_{2} \mathrm{O}$. The RCP30 showed the highest recrystallized yield of $51.0 \%$, whereas the highest soluble percentage of $99.16 \%$ was observed from RCP50. Applying the SEM technique, the plate of crystal intersperse in different sizes of RCP30 was observed, whereas the RCP50 and RCP80 show the coagulate crystal plate. The formation and purity of the soluble $\mathrm{Ca}\left(\mathrm{H}_{2} \mathrm{PO}_{4}\right)_{2} \cdot \mathrm{H}_{2} \mathrm{O}$ and non-soluble $\mathrm{CaHPO}_{4} \cdot 2 \mathrm{H}_{2} \mathrm{O}$ compounds were confirmed by the $\mathrm{X}$-ray diffractograms. Various vibrational modes of $\mathrm{HPO}_{4}{ }^{2-}, \mathrm{H}_{2} \mathrm{PO}_{4}^{-}$, and $\mathrm{H}_{2} \mathrm{O}$ presented in the crystal structure of the synthesized products observed from the infrared adsorptions also confirm the characteristic of $\mathrm{Ca}\left(\mathrm{H}_{2} \mathrm{PO}_{4}\right)_{2} \cdot \mathrm{H}_{2} \mathrm{O}$ and $\mathrm{CaHPO}_{4} \cdot 2 \mathrm{H}_{2} \mathrm{O}$. The thermal decomposition of the recrystallized products was investigated. The thermal dehydration of physisorbed water, polycondensation (dehydroxylation), and re-polycondensation processes were observed, and $\mathrm{CaP}_{2} \mathrm{O}_{6}$ is the final thermodecomposed product.

\section{Acknowledgments}

The authors would like to thank the Scientific Instruments Center KMITL for supporting TGA, FTIR, XRD, and SEM techniques. This work was supported by the Thailand Science Research and Innovation (TSRI) (RE-KRIS/008/64).

\section{References}

1. Boonchom, B. and C. Danvirutai, The morphology and thermal behavior of Calcium dihydrogen phosphate monohydrate (Ca (H2PO4) 2 $\mathrm{H} 2 \mathrm{O}$ ) obtained by a rapid precipitation route at ambient temperature in different media. J. Optoelectron. Biomed. Mater, 2009. 1: p. $115-123$.

2. LeGeros, R. and H. Myers, Monographs in oral science. Calcium Phosphates in Oral Biology and Medicine. San Francisco: Karger, 1991: p. 131.

3. Sánchez-Enríquez, J. and J. Reyes-Gasga, Obtaining Ca (H2PO4) 2· H2O, monocalcium phosphate monohydrate, via monetite from brushite by using sonication. Ultrasonics sonochemistry, 2013. 20(3): p. 948-954.

4. Hsu, Y.-S., E. Chang, and H.-S. Liu, Hydrothermally-grown monetite (CaHPO4) on hydroxyapatite. Ceramics international, 1998. 24(4): p. 249-254.

5. Green, B., Fertilizers in aquaculture, in Feed and Feeding Practices in Aquaculture. 2015, Elsevier. p. 27-52.

6. Gonzalez-McQuire, R., et al., Synthesis and characterization of amino acid-functionalized hydroxyapatite nanorods. Journal of materials chemistry, 2004. 14(14): p. 2277-2281.

7. Nasri, K., et al., Recrystallization of industrial triple super phosphate powder. Industrial \& Engineering Chemistry Research, 2014. 53(37): p. 14446-14450. 
8. Liu, J., et al., Rapid formation of hydroxyapatite nanostructures by microwave irradiation. Chemical physics letters, 2004. 396(4-6): p. $429-432$.

9. Kumar, R., et al., Temperature driven morphological changes of chemically precipitated hydroxyapatite nanoparticles. Langmuir, 2004. 20(13): p. 5196-5200.

10. Ma, M.-G., Y.-J. Zhu, and J. Chang, Monetite formed in mixed solvents of water and ethylene glycol and its transformation to hydroxyapatite. The Journal of Physical Chemistry B, 2006. 110(29): p. 14226-14230.

11. Liu, D.-M., et al., Structural evolution of sol-gel-derived hydroxyapatite. Biomaterials, 2002. 23(7): p. $1679-1687$.

12. Djošić, M., et al., Electrochemical synthesis of nanosized monetite powder and its electrophoretic deposition on titanium. Colloids and Surfaces A: Physicochemical and Engineering Aspects, 2009. 341(1-3): p. 110-117.

13. Seesanong, S., C. Laosinwattana, and B. Boonchom, A simple rapid route to synthesize monocalcium phosphate monohydrate using calcium carbonate with different phases derived from green mussel shells. J Mater Environ Sci, 2019. 10: p. 2-113.

14. Chalermwat, K., B. Szuster, and M. Flaherty, Shellfish aquaculture in Thailand. Aquaculture Economics \& Management, 2003. 7(3-4): p. 249-261.

15. Chilakala, R., et al., Sustainable solutions for oyster shell waste recycling in Thailand and the Philippines. Recycling, 2019. 4(3): p. 35.

16. Seesanong, S., et al., Composition and Properties of Triple Superphosphate Obtained from Oyster Shells and Various Concentrations of Phosphoric Acid. ACS omega, 2021. 6(34): p. 22065-22072.

17. Sronsri, C. and B. Boonchom, Synthesis, characterization, vibrational spectroscopy, and factor group analysis of partially metal-doped phosphate materials. Spectrochimica Acta Part A: Molecular and Biomolecular Spectroscopy, 2018. 194: p. $230-240$.

18. Sronsri, C., Thermal dehydration kinetic mechanism of Mn1.8Co0.1Mg0. 1P2O7·2H2O using Málek's equations and thermodynamic functions determination. Transactions of Nonferrous Metals Society of China, 2018. 28(5): p. 1016-1026.

19. Sronsri, C. and B. Boonchom, Thermal kinetic analysis of a complex process from a solid-state reaction by deconvolution procedure from a new calculation method and related thermodynamic functions of Mn0. 90Co0. 05Mg0. 05HPO4. 3H2O. Transactions of Nonferrous Metals Society of China, 2018. 28(9): p. 1887-1902.

20. Sronsri, C., U. Kongpop, and W. Sittipol, Quantitative analysis of calcium carbonate formation in magnetized water. Materials Chemistry and Physics, 2020. 245: p. 122735.

21. Sronsri, C. and B. Boonchom, Deconvolution technique for the kinetic analysis of a complex reaction and the related thermodynamic functions of the formation of LiMn0. 90Co0. 05Mg0. 05PO4. Chemical Physics Letters, 2017. 690: p. 116-128.

Johnston, A. and I. Richards, Effectiveness of the water-insoluble component of triple superphosphate for yield and phosphorus uptake by plants. The Journal of Agricultural Science, 2003. 140(3): p. 267-274.

23. Nosrati, H., et al., Nucleation and growth of brushite crystals on the graphene sheets applicable in bone cement. Boletín de la Sociedad Española de Cerámica y Vidrio, 2020.

24. Mathew, M. and S. Takagi, Structures of biological minerals in dental research. Journal of Research of the National Institute of Standards and Technology, 2001. 106(6): p. 1035.

25. Schofield, P., et al., The role of hydrogen bonding in the thermal expansion and dehydration of brushite, di-calcium phosphate dihydrate. Physics and Chemistry of Minerals, 2004. 31(9): p. 606-624.

26. Curry, N. and D. Jones, Crystal structure of brushite, calcium hydrogen orthophosphate dihydrate: a neutron-diffraction investigation. Journal of the Chemical Society A: Inorganic, Physical, Theoretical, 1971: p. 3725-3729.

27. Dosen, A. and R.F. Giese, Thermal decomposition of brushite, CaHPO4. $2 \mathrm{H} 2 \mathrm{O}$ to monetite CaHPO4 and the formation of an amorphous phase. American Mineralogist, 2011. 96(2-3): p. 368-373.

28. Sainz-Díaz, C.I., A. Villacampa, and F. Otálora, Crystallographic properties of the calcium phosphate mineral, brushite, by means of First Principles calculations. American Mineralogist, 2004. 89(2-3): p. 307-313.

29. Dickens, B. and J. Bowen, Refinement of the crystal structure of Ca (H2PO4) 2. H2O. Acta Crystallographica Section B: Structural Crystallography and Crystal Chemistry, 1971. 27(11): p. 2247-2255. 
30. Tortet, L., et al., Study of protonic mobility in CaHPO4. 2H2O (brushite) and CaHPO4 (monetite) by infrared spectroscopy and neutron scattering. Journal of solid state chemistry, 1997. 132(1): p. 6-16.

31. Boonchom, B., Parallelogram-like microparticles of calcium dihydrogen phosphate monohydrate (Ca (H2PO4) 2· H2O) obtained by a rapid precipitation route in aqueous and acetone media. Journal of alloys and compounds, 2009. 482(1-2): p. $199-202$.

32. Desai, T.R., S.B. Bhaduri, and A.C. Tas. A Self-Setting, Monetite (CaHPO 4) Cement for Skeletal Repair. in Ceramic engineering and science proceedings. 2007. Wiley Online Library.

33. Ferna, E., et al., Calcium phosphate bone cements for clinical applications. Part II: precipitate formation during setting reactions. Journal of Materials Science: Materials in Medicine, 1999. 10(3): p. 177-183.

34. Kasuga, T., et al., Surface modification of calcium metaphosphate fibers. Journal of Materials Science: Materials in Medicine, 2000. 11(4): p. 223-225.

35. Kasuga, T., et al., Preparation of high - strength calcium phosphate ceramics with low modulus of elasticity containing $\quad \beta$ - Ca (PO3) 2 fibers. Journal of the American Ceramic Society, 1996. 79(7): p. 1821-1824. 